9. PRESENTATION OF THE WIENERWALD BIOSPHERE RESERVE AND INTRODUCTION TO FIELD TRIP

by Günther Loiskandl

\section{GEOGRAPHY AND LANDSCAPE}

The Wienerwald covers parts of the provinces of Vienna and Lower Austria in the west and southwest of the city of Vienna. As it is the easternmost part of the Alps, the Wienerwald is a hilly and slightly mountainous area with altitudes from 160 to 893 metres above sea level. It is fragmented by numerous small rivers and valleys. In the North it slopes down towards the Tullnerfeld plain and to the river Danube. Rolling hill regions form the eastern foothills, that expand into the city of Vienna. Further south, the eastern slopes of the Wienerwald form the transition area to the Vienna Basin, that is known as the "Thermal line", a geological rupture zone with thermal springs.

\section{GEOLOGY}

The Sandstone Wienerwald extends over some four fifths of the total area. It is made up of flysch and characterised by smoothe surface shapes and broad humps. The moderate sloped ridges reach up to just 540 metres above sea level and have hardly any distinct peaks. The underlying structures are water impermeable thus favouring small-scale waterloggings. V-shaped small valleys with peaks of water flow after heavy precipitation are a rather characteristic feature.

The Limestone Wienerwald is characterised by sheer slopes with steep rock faces and formations. Narrow gorges and steep valleys cut through limestone and dolomite rocks. Due to the jagged nature of the surface and the highly soluble limestone, water runs well into underlying structures. Underground drainage patterns form karst formations and caves.

\section{CLIMATE}

As it is a barrier for the most usual west-winds the Wienerwald is a weather divide. Central European oceanic climate meets Pannonic sub-continental cli- mate with cold winters and dry, hot summers. Precipitation decreases from northwest (up to 1000 $\mathrm{mm}$ ) to southeast (approx. $600-700 \mathrm{~mm}$ ). Mean annual temperature is $7^{\circ} \mathrm{C}$ in the central part of Wienerwald and $9^{\circ} \mathrm{C}$ in the easternmost part with Pannonic influence.

\section{LANDCOVER AND HABITATS}

The Wienerwald is an important biodiversity "hot spot" throughout Europe. Diverse types of habitats have developed here due to numerous factors such as the meeting of different biogeographical and climatic regions, different geological conditions, considerable altitude difference and last but not least the human influence.

Large areas of the Wienerwald are contiguously wood covered (more than 60\%). The dominant tree species is beech (Fagus sylvatica). But among the 25 different types of forest-vegetation there are not just different kinds of beech forests. Austria's largest forests of downy oak (Quercus pubescens) and subMediterranean pine forests with the endemic Austrian pine (Pinus nigra) at the easternmost edge of the region are of European significance.

The habitats in open-land cultivated area in the Wienerwald are aswell of outstanding international importance. Vast meadows and pastures which are the result of centuries of cultivation, dominate large parts of the region. Dry grasslands are particularly characteristic. There are also few unimproved neutral grasslands on moist and wet sites. On the easternmost edge of this region, elements of eastern European steppe and calcareous dry meadows are dominant. Ancient vineyards and fruit orchards, areas dominated by agriculture, rich sources of water and numerous structural elements enrich the landscape diversity of the Wienerwald.

\section{FLORA AND FAUNA}

The high level of habitat diversity is the prerequisite for the extraordinary diversity of species in terms of quality as well as quantity - and here too, Wienerwald is of great significance on a European level.

In the Wienerwald there are 120 breeding bird 
species, such as black stork (Ciconia nigra), many species of woodpeckers, corncrake (Crex crex) and the largest Population of woodlark (Lullula arborea) in Austria. Notable mammal-populations are those of a number of rare bat species, of the European ground squirrel (Citellus citellus) and of red deer (Cervus elaphus). Outstanding amphibians and reptiles are yellow-bellied toad (Bombina variegata), Alpine crested newt (Triturus carnifex), fire salamander (Salamandra salamandra), smooth snake (Coronella austriaca) and green lizard (Lacerta viridis). Austria's largest populations of many deadwood dwelling beetle species can also be found here. Extraordinary rich is the arthropod fauna of meadows and grasslands in the region. A long list of plants of national and international importance can be found in the woods and in the open-land areas of the Wienerwald.

\section{HUMAN POPULATION - COMMUNITIES - ECONOMY}

The Biosphere Reserve Wienerwald is close to the agglomeration of Vienna, Austria's most important economic area. In Lower Austria 51 communities with about 282,000 inhabitants are completely or partly within the Biosphere Reserve. Parts of seven municipal districts of Vienna with a population of about 477,000 are area of the Biosphere Reserve. So more than 750.000 people are living in the region that is up to start a development processes to a model-region for sustainability. This high population is a challenge for public relations aswell as for participation.

In particular the Biosphere Reserve communities south of Vienna perform high economic power. Althought the majority of the population and industrial sites, settlement areas and business premises

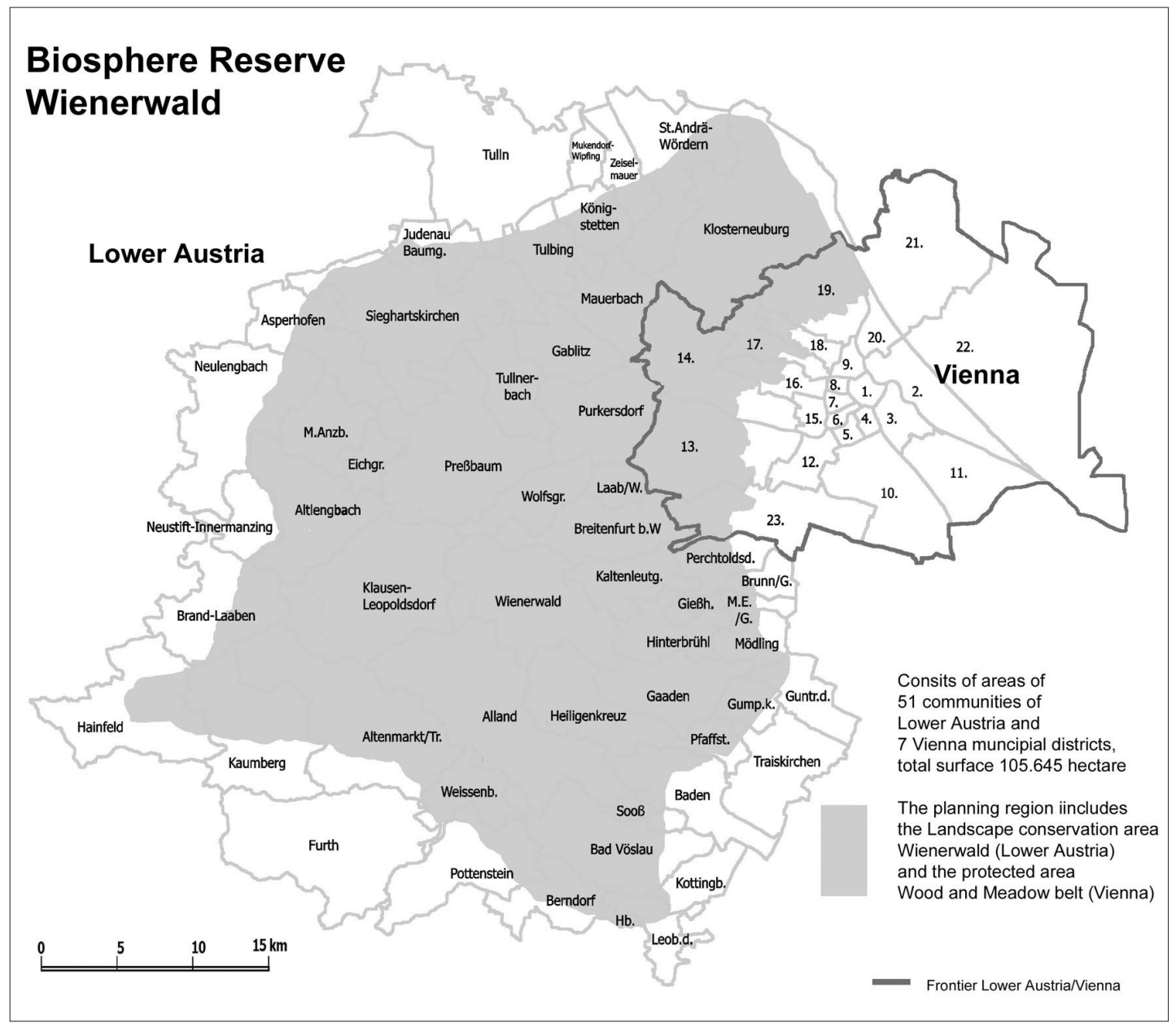


here and in Vienna's municipal districts are located outside, there are multifunctional interrelations with the Biosphere Reserve territory. As implied by the term "outer transition area", the boundaries of the Wienerwald Biosphere Reserve have to be seen flexible, respecting the links between the Biosphere Reserve and the surrounding areas.

\section{LAND-USE}

Man started to settle in the Wienerwald some thousand years ago. The dense woodland was opened and the landscape was enriched by cultivated land. The predominant forms of land use in open-land cultivated areas - grassland and arable farming have created a characteristic cultural landscape. Meadows and pastoral use are still important in some areas which are often of great value in terms of nature conservation. Somehow compensating massive losses in milk production horse-keeping for riding has greatly increased. At the eastern fringe of the Biosphere Reserve fruit and wine growing complement arable farming. Extensively used sites such as pastures or wetland meadows, often survived in unfavourable locations. However, these rare, valuable habitats are endangered, aswell as the Wienerwald landscape in general, by abandoning and intensifying of the agricultural land use.

Forestry has influenced almost all forest areas in the Wienerwald quite considerably. The woods have been used for more or less intensive commercial timber production since centuries. Since mid 19th century the forests in this area have been managed according to sustainable and nature-friendly criteria. However, in wide areas of the forest ecosystems significant aspects of natural processes have been affected by human intervention and use. Age-class forests dominate in wide areas. But sites with nonindigenous trees are rare.

Especially along the edges of the Wienerwald and in valleys there are densly populated areas. Suburban residential areas are rather "green" and of some value for species. But the Wienerwald faces major challenges bound to the future development of space-use for settling. As a "green space" with high life-quality close to the agglomeration of Vienna the
Wienerwald has been and still is extremely attractive as a residential area. Settlement development is characterised by suburbanisation and urban sprawl. Future urban and regional planning has to deal with the question about limits for settlement and population development. Closely connected are challenges by mobility, traffic and transportation. Landscape fragmentation particularly because of main traffic routs is one of the serious topics.

Since the 19th century the Wienerwald has become an attractive and important recreational space for the population of and around Vienna. People living in and in the immediate vicinity of the Biosphere Reserve frequently use the "green-lung of Vienna" for walking, cycling, mountain biking and other outdoor activities. No wonder, the pressure by recreational use is very high in some parts of the Wienerwald. In the future measures to manage and concentrate the visitor flows must be developed together with landowners, farmers, visitors and residents. The Biosphere Reserve will be an instrument to support improvements and solutions for conflicts between differing interests.

\section{CULTURAL SIGNIFICANCE}

Biosphere Reserve Wienerwald and its surroundings offer a wide range of tourist attractions of high cultural value, not including the outstanding sights in the neighbouring city of Vienna.

Numerous prehistoric archaeological sites are dating back to the Neolithic period. Celts and Illyrians settled in this region as early as $300 \mathrm{BC}$, followed by the presence of the Romans.

Monasteries once played an important role in the history of early settlements in the primeval forests. These were and still are significant cultural and religious destinations. Numerous castles and castle ruins are evidence of the turbulent history of this region during the Middle Ages, when Wienerwald formed the border against the east. There are also numerous historical buildings dating back to the late Middle Ages and the subsequent epochs in towns and villages surrounding the Wienerwald region. The historical centre of the Baroque town Baden is contiguous to the Biosphere Reserve. Baden is not 
only the most significant tourist centre in Lower Austria, but also of particular cultural interest, offering a wide range of facilities: spa resorts, casino, theatre, and tourist attractions.

In the 19th century, during the Biedermeier period, many artists "discovered" Wienerwald. Natural landscapes and countryside idyll of the Wienerwald region became popular motifs of Romanticism landscape painting. Great Biedermeier painters depicted a quite detailed portrait of the people and nature of Wienerwald region of that time. Composers such as Franz Schubert, Johann Strauß and Ludwig van Beethoven were also inspired by the landscapes of Wienerwald. Wolfgang Amadeus Mozart spent some summer holidays in Baden.

\section{HISTORY OF PROTECTION UP TO THE INTER- NATIONAL RECOGNITION AS A BIOSPHERE RESERVE}

Ideas and efforts to protect the unique landscape and nature values of the Wienerwald have a long history. In the middle of 19th century wide areas of the Wienerwald were seriously in danger of being clear cut and split into small parcels for building and settlement activities. A clever public campaign against this overexploitive deforestation waged by Josef Schöffel, the major of the city of Mödling, was successful. Since this Schöffel is regarded as the saviour of the Wienerwald.

The high quality as a recreation area and new transport opportunities gave rise to settlement activities in the Wienerwald in late 19th century. It almost looked like the city of Vienna would spread towards west, up the hills of the Wienerwald, without any limits. As a result as early as 1905 the city council of Vienna declared the "forest and meadow belt protected area" around Vienna, in order to supply fresh, clean air and to safeguard the recreation area. Later on the Wienerwald has faced several other legal protection instruments. Due to its importance for biodiversity and for human recreation the total area of the Wienerwald was declared a landscape conservation area. Some sites of extraordinary value are nature conservation areas or natural monuments. Four nature parks were installed to offer spe- cial opportunities for recreation in nature. Latest large-scale contributions to the European protectedarea network "Natura 2000" were made.

When the first Austrian National Parks had already been successfully installed in the 1990 ies, conservation organisations started a call for a Nationalpark Wienerwald.

In 2002 the Federal States of Lower Austria and Vienna together set up strong initiatives for the future of the Wienerwald: Considering the first use of the term "Wienerwald" in a document in 1002, millennium celebrations focussed on rising public attention on the future of the area. Over the entire year numerous expert discussions, exhibitions and cultural events took place.

On the basis of the old "Wienerwald Declaration" of 1987 Lower Austria and Vienna formulated advanced objectives and measures aimed at maintaining the Wienerwald for future generations as a natural and recreational environment. This new "Wienerwald Declaration 2002" is a comprehensive catalogue for sustainable regional development in the Wienerwald region, involving all participants. It can be seen as an overall guideline for establishing and developing the Biosphere Reserve Wienerwald as a pilot site for sustainable development. Almost all towns and villages of the region and those municipal districts of Vienna that include parts of the Wienerwald signed the declaration and thus joined this initiative.

In the same year the provincial governments of Vienna and Lower Austria ordered a feasibility study to clarify which conservation category would be more suitable for the region, National Park or Biosphere Reserve. Ás a result a National Park was considered not to be the adequate instrument for the specific situation of the Wienerwald. The UNESCO Biosphere Reserve concept on the other hand was recommended as the ideal alternative. It would take in account the character of the Wienerwald as one of the ecologically most important regions of Austria but also its function as a traditional recreation area and economically utilised landscape.

Based on this recommendation the governments of 
Plenary Presentation and Workshop Results

\section{CHAPTER IV}

Vienna and Lower Austria decided to prepare and to install a Biosphere Reserve according to the UNESCO guidelines and the Sevilla Strategy in the Wienerwald.

In 2003 the provinces of Lower Austria and Vienna jointly installed the Biosphere Reserve Wienerwald Management. It works in close co-operation with and reports to authorities of the two provinces. Major goals were to work out the UNESCO nomination form, to co-ordinate all the necessary planning and to communicate the rising initiative towards a Biosphere Reserve to local population and stakeholders.

The Austrian National MAB Committee of the Austrian Academy of Science proofed the Nomination and referred it to UNESCO in Paris. In June 2005 UNESCO approved the nomination and the Wienerwald was officially recognised as a "Biosphere Reserve".

\section{AREA AND LAND TENURE}

The total area of 105.645 hectares of the Biosphere Reserve Wienerwald stretches over the territories of the two Federal States of Lower Austria $(95,688$ hectares, i.e. $90.6 \%)$ and Vienna $(9,957$ hectares, i.e. $9.4 \%)$.

Approx. 35,000 hectares (33.3\%) of the Biosphere Reserve Wienerwald area (approx. 33,000 hectares of forests, rest meadows, other not forested area) are property of the Republic of Austria, administrated and managed by the Austrian Federal Forests (Stock Company, 100\% shares held by the Republic of Austria). The rest is property of the City of Vienna, local communities and private owners. Among the numerous private owners there are several with property in the dimension of some hundred, or up to some thousand hectares (e.g. the Catholic Church with properties and some monasteries).

\section{ZONATION}

Designing the zonation of the Biosphere Reserve was a major concern in the planning process. Althought several legal instruments for nature protection had already been implemented in the Wienerwald, especially the demand for strictly protected core zones of the Biosphere Reserve had to be met by a totally new approach.

\begin{tabular}{|l|r|r|}
\hline & area [ha] & \% of the total area \\
\hline Total area Biosphere Reserve Wienerwald & 105,645 & 100.0 \\
\hline Core zones total & 5,576 & 5.3 \\
\hline Buffer zone total & 19,840 & 18.8 \\
Buffer zone forest & 4,887 & 4.6 \\
Buffer zone open-land cultivated area & 14,953 & 14.2 \\
\hline Outer transition area & 80,229 & 75.9 \\
\hline
\end{tabular}
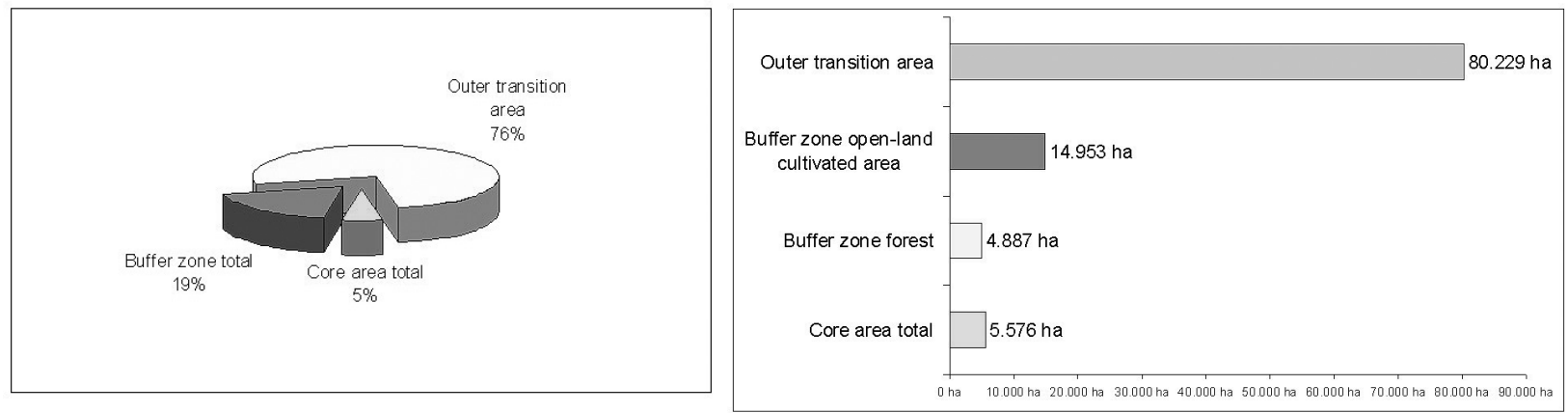


\section{CORE ZONES}

Core zones were selected in an intensive planning process that lasted more than two years. The selection was based on latest scientific research findings with consideration of a broad variety of criteria and made in consultation with noted experts and participation of owners. During the planning period, owners refrained from using possible core zones and as an exchange, the Federal States of Lower Austria and Vienna paid contractually stipulated compensations. This way, potential core zones were preserved throughout the planning process.

In Future owners of core zones will get compensational payment by the Federal States of Lower Austria and Vienna for giving up forestrial use. Agreements about this will be fixed in treaties between the owners and the provinces. To constitute the core zones by strict sovereign jurisdiction they will be declared as Nature conservation areas. 36 core zones will guarantee long-term protection and natural development of forest areas.

\begin{tabular}{|l|r|r|}
\hline owners & oarea [ha] & \% of the total core zones \\
\hline $\begin{array}{l}\text { Republic of Austria (managed by } \\
\text { the Austrian Federal Forests) }\end{array}$ & 4,242 & 76.0 \\
\hline Other private land owners & 609 & 10.9 \\
\hline Church and monasteries & 288 & 5.3 \\
\hline City of Vienna & 275 & 4.9 \\
\hline Municipalities & 162 & 2.9 \\
\hline Total & 5,576 & 100.0 \\
\hline
\end{tabular}

The mosaic pattern of core zones allows to represent different types of forests in protected areas. The individual core zones are important as stepping stones within the network of the protected area which they are part of.

Strict and long-term protection without human use and intervention is a suitable strategy for habitats with long development periods like the forests in the Wienerwald Biosphere Reserve. For other types of Wienerwald-specific habitats, such as meadows and pastures, the classification as core zone would not be appropriate, since in these areas controlled human use and intervention is essential. Therefore, in the Wienerwald Biosphere Reserve only forests have been designated as core zones. Just as in other parts of central Europe, the Wienerwald region no longer includes any pristine forests owing to centuries of human use and intervention. Therefore the starting point for future forest development in the core zones will be the previously semi-naturally managed forests, which show great potential for reversion to a primeval stage. There will be no more forest use in the core zones to fulfil the conservation of natural processes.

\section{BUFFER ZONES (PFLEGEZONEN)}

Like the core zones the buffer zones were selected in an intensive planning process, based on latest research findings, with consideration of a broad variety of criteria and made in consultation with noted experts. Other than in case of the core zone planning process it was impossible to participate thousands of owners of buffer zones. Participation and information during the planning process was achieved by inflicting representatives of interestgroups.

Following the example of Biosphere Reserves in the German speaking countries, in case of Biosphere Reserve Wienerwald the German term "Pflegezone" will stand for buffer zone. Althought legally constituted buffer zones will - in difference to core zones - not statue new legal restrictions. They will rather mark important and valuable areas that shall face special attention and specific management. 
Measures will be taken voluntarily.

Conventional buffer functions are fulfilled by forest buffer zones surrounding or contiguous to core zones. In addition, specific forest areas which, despite meeting some of the suitability criteria, have been considered unsuitable as core areas (e.g. because of the large number of visitors) will face special attention as buffer zones, aswell as all water courses and their banks in forests.

Forestry may be continued here, but special attention has to be paid to conservation objectives. Detailed objectives and specific measures for a particularly considerate and semi-natural management with a view to the conservation objectives are being prepared in a participatory process with the owners, managing bodies and other groups of interest and will be laid down as an overall guideline.

Open land, nonwooded areas outside settlements, dominated by agricultural land use, still shows a rich and diversely structured landscape with species-rich meadows, pastures, fields, locally typical fruit- and vine yards and waters. These particularly important habitats were formed by agricultural use. During the last decades, the methods of land-use have changed considerably, and unfortunately they now endanger the cultural landscape. The situation is even more dramatic, where farming activities have been abandoned: forest and settlements tend to spread across meadows, pastures and fields.

Open-land buffer zones are essential tools for drawing attention to the most outstanding open-land areas. They identify open-land areas where conservation and management policies are required to maintain the natural value. Traditional farming practices might be the best management here. Unlike in core areas, in the buffer zone land cultivation is acceptable or even necessary and should therefore be maintained. Farmers who apply nature friendly and resource conservationist land-use methods are the "managers" of open-land buffer zones. Safeguarding the existence of farming enterprises through various measures will thus be of key significance. One of the priority objectives is to market products and services offered by farmers as good and as effective as possible. Public awareness of the causal relationship between consumer habits and the beautiful Wienerwald landscapes has to be increased.

\section{OUTER TRANSITION AREA (ENTWICKLUNGS- ZONE)}

The outer transition area includes all areas within the Biosphere Reserve which are not core zones or buffer zones, i.e. all urban, suburban and rural settlements in the Biosphere Reserve as well as roads, railways and even motorways. Large parts of the transition area, however, are covered by open land which is mainly used for farming. 56,376 hectares of sustainable managed forests cover the largest surface of the outer transition area.

In the Lower Austrian sector the total area of the biosphere reserve, and so the outer transition area, has the status of a landscape conservation area. Large parts of the Vienna sector of the transition area also have the status of a landscape conservation area.

Comprehensive information and education of people should gradually raise their awareness and help motivate and mobilise them to actively contribute to regional sustainable development. Future issues of particular importance are settlement and human development, and related questions concerning mobility and transportation, as well as the use of land as a natural resource. For the conservation of cultural landscapes it is essential to maintain an environmental- and nature-friendly agricultural use. Therefore the owners and managing bodies should be supported in obtaining public appreciation. Increase of regional profitability has to be achieved for cultivation in conformity with the principles of nature conservation. In this respect, the vicinity to the urban agglomeration area of Vienna offers rather good opportunities.

Accompanying research and monitoring will document the human impact on the environment. Future recommendations for a comprehensive sustainable development will be supported by the findings of research programmes.

Tourism and regional recreation offer both business opportunities and higher quality of life for local citi- 
zens. However, the best possible coordination is indispensable, since tourism and recreation are closely related to land-use and environmental protection issues.

\section{LEGAL AND ORGANISATIONAL BASIS OF BIOSPHERE RESERVE WIENERWALD}

The legal basis for Biosphere Reserve Wienerwald are the Acts on the Biosphere Reserve Wienerwald for Lower Austria and Vienna and a treaty between the two Federal States on the joint implementation and maintenance of Biosphere Reserve Wienerwald. The Biosphere Reserve Wienerwald Management will be organised as an independent company (Ltd). It will be backed and financed by the Federal States of Lower Austria and Vienna and will closely cooperate with governmental departments and authorities of the two federal states. The Biosphere Reserve Wienerwald Management will function as the coordination centre in the region - a unique institution. Biosphere Reserve Management will give new impulses to the region for sustainable development. It will present opportunities and point out potentials and support the numerous action plans, organisations and projects in the region.

\section{PARTICIPATION}

The concept of Biosphere Reserves based on the Seville Strategy met with a very positive response in the Wienerwald region. At numerous information events by the Biosphere Reserve Management people have shown a generally active interested basic attitude with regard to the Biosphere Reserve. A large number of individual contacts served to collect ideas and to find potential forerunners for the future development in the Biosphere Reserve.

In view of the large number of municipalities and districts and the high population density in the region, participation processes constitute a particular challenge. Successful participation models have already been established in form of participatory bodies in the following spheres: forest \& forestry, open-land cultivated areas \& agriculture and hunting \& game management. In these "advisory forums" the individual planning stages were period- ically presented to and discussed and coordinated with all parties concerned. In addition thematic guidelines for the development of the biosphere reserve were being elaborated. Additional advisory forums are planned for focal issues such as regional planning and transport, tourism and recreational use, regional economic development and energy. In the future a scientific advisory council is planned to support the advisory forums and the Biosphere Reserve Wienerwald Management. Special importance is attached to the regional forum as a platform for the official representatives of the municipalities and districts of the region.

\section{MANAGEMENT POLICY AND MECHANISMS FOR IMPLEMENTATION}

With the 2002 Wienerwald Declaration, which was passed with regard to the Biosphere Reserve Wienerwald by the two Federal States of Lower Austria and Vienna, there exists a comprehensive catalogue of objectives and activities for an integrative, sustainable regional development in region. It serves as an overall guideline for the development of the Biosphere Reserve Wienerwald into a pilot site for sustainability.

In order to put the Wienerwald Declaration into concrete terms, guidelines for important focal issues and for homogeneous sub-regions are to be elaborated in the context of the development of the Biosphere Reserve. A framework concept for the protection, maintenance and development of the Biosphere Reserve Wienerwald is to combine the contents of the different guidelines and constitute a comprehensive basis for the development of the Wienerwald region as a Biosphere Reserve.

\section{APPROACHES TO AN ECOLOGICALLY, ECO- NOMICALY AND SOCIO-CULTURALLY SUS- TAINABLE DEVELOPMENT}

The vicinity of Biosphere Reserve Wienerwald to Austria's most important economic and urban areas offers a great opportunity on an international scale: Here, under rather difficult circumstances, the basic idea of biosphere reserves can be put into practice, that is to implement an instrument to develop a 
"pilot site" for comprehensive sustainability in an environment dominated by urban life. Sustainable development is already being promoted in the Wienerwald region: Sustainable development is the declared strategic objective of both Federal States of Lower Austria and Vienna. The federal government is also very much interested in supporting sustainability in pilot sites. Numerous municipalities and districts already recognised the opportunities which a biosphere reserve would offer. And last but not least, the population of this region shows great interest in the Biosphere Reserve.

There are already various ongoing action plans, projects and cooperations between municipalities, companies and organisations which have all one common goal: promoting and maintaining sustainable development. Here are some examples:

- Most municipalities in Lower Austria and Vienna municipal districts located in the Biosphere Reserve Wienerwald region have voluntarily joined the Wienerwald Declaration 2002 for sustainable development.

- 28 municipalities are members of the Climate Alliance and have implemented various measures for climate protection. 26 municipalities cooperate in the project "Verkehrsparen Wienerwald" (traffic reduction programme in Wienerwald). One of the objectives of Biosphere Reserve Wienerwald will be to increase the number of municipalities taking part in the above mentioned initiatives.

- Numerous municipalities actively participate in village and town regeneration programmes; many municipalities cooperate on a regional level as subregions and implement measures for sustainable development. Biosphere Reserve Wienerwald will improve and intensify cooperation between the municipalities.

- The "Heubörse Wienerwald" (Wienerwald hay exchange) acts as a successful agent between producers and purchasers of high-quality hay thus contributing to the conservation of meadows in the Wienerwald region.

- Farmers and business enterprises cooperate in the association "Vermarktungsgemeinschaft
Wienerwald" (marketing cooperation Wienerwald) for better marketing of their regional quality products. Biosphere Reserve Wienerwald Management actively supports the further development and strengthening of this initiative.

- Subregional development action plans for subregions provide self-determined general guidelines for sustainable development. This is an attempt to meet the requirements of sustainable development on the regional level.

- The "Action plan for sustainable development in Biosphere Reserve Wienerwald" will help to make tangible the basic idea of sustainability and to make it measurable by offering indicators.

- The forestry sector has great potential for further development along the modern idea of sustainability. A number of business enterprises have already adapted this idea.

- A large number of farms apply farming methods which are compatible with the criteria of biological agriculture. One of the objectives of Biosphere Reserve Wienerwald will be to increase the number of "organic farmers" and to develop and/or find new markets for their products.

- In the Wienerwald region, there is great potential for agriculture and associated fields of business in equestrian sports and horse husbandry, in wine and fruit growing with local direct marketing, as well as in biomass energy production.

- The establishment of a biosphere reserve might be an opportunity to change attitudes in tourism industry of the area: new, self-imposed quality standards will guarantee that the basic idea of sustainable development is always followed.

- In the Wienerwald region there is great demand for innovative products from the fields of agri culture, forestry, trade and tourism, which correspond to the criteria of sustainable production and/or cultivation methods.

- The abundance of forest areas in the Wienerwald region makes Wienerwald best suited for becoming a pilot site for biomass energy generation. 


\section{RESEARCH AND MONITORING}

Thousands of scientific papers make the Wienerwald region on of the most thoroughly researched areas of Austria. Research activities in the Wienerwald region have up to now lacked a central coordination. It can be assumed that many different institutions are carrying out individual research and monitoring projects. Since there are a rather large number of research and monitoring institutions within and in the immediate vicinity of the Wienerwald region, it will be almost impossible to establish a centralised coordination and documentation in this area. But the Biosphere Reserve Wienerwald Management will attempt to provide a coordination plattform for research and monitoring in the Wienerwald region, in close cooperation with the National MAB Committee and other partners. In order to achieve this goal, it is essential to establish relationships and contacts with as many research institutions and stake holders as possible. Presently, the Biosphere Reserve Wienerwald Management closely cooperates with eleven university institutes in four different universities (at the moment, more than ten thesis are in progress, which are supported by the Biosphere Reserve Wienerwald Management) and with 12 non-university research institutions.

The following scientific planning projects were commissioned by the administrations of the two Federal States of Lower Austria and Vienna and by the Biosphere Reserve Wienerwald Management, to meet the demands of the planning process and future management issues:

- Feasibility Study Wienerwald: Suitability of the Wienerwald area as a National Park or Biosphere Reserve; collecting data on the manifold claims of use in the Wienerwald region and its assets of protection; preparing of a general zonation plan; technical basis for the (regional) political decision-making process ("pro" biosphere reserve) and for the detailed planning and implementation stage

- Regional Analysis Wienerwald: Comprehensive evaluation of socio-economic aspects of the Wienerwald region, and of exchanges with the surrounding areas, with special focus on the urban agglomeration area of Vienna

- Biosphere Reserve Wienerwald Planning Project for Forests:

Zonation planning in forest areas (core zones, buffer zones); Suggestions for development objectives and management measures for forests in all three zones; Participatory process including interest groups, stake holders and land owners

- Biosphere Reserve Wienerwald Planning Project for Open-land and Agriculture:

Zonation planning in open-land (non-residential areas, not covered by forests and mainly used for agricultural activities) - buffer zones;

Suggestions for development objectives and management measures for open-land and farming areas in buffer zones and the outer transition area; Participatory process including interest groups, stake holders and land owners (cultivated areas and agriculture)

- Biosphere Reserve Wienerwald Planning Project for Sustainable Developement: Preparing a concept for sustainable regional development in the Biosphere Reserve Wienerwald; suggestions for development opportunities and objectives, possible measures and guidelines for a sustainable development in the fields of regional planning, residential and recreational use, economic development, tourism, use of energy and resources, cooperation between communities, ...; Participatory process

- Biosphere Reserve Wienerwald Planning Project for Participation and Communication:

Consulting and suggestions for organisational structures and methods for participation and communication

- Concept for Research and Monitoring in the Biosphere Reserve Wienerwald ongoing, to be finished in 2005:

Development of a concept for research and monitoring in the Biosphere Reserve Wienerwald, with special consideration of BRIM 
ENVIRONMENTAL EDUCATION AND PUBLIC AWARENESS ACTIVITIES

In 2002, when the Federal States of Lower Austria and Vienna jointly decided to nominate the Wienerwald region for designation as a Biosphere Reserve, the concept was hardly known in Austria, even less in Eastern Austria. So, when the Biosphere Reserve Wienerwald Manager was appointed in the beginning of 2003 , one of his primary tasks in the planning process for the biosphere reserve was to give comprehensive information about the UNESCO Biosphere Reserve concept. Providing information and raising public awareness in the region was just the beginning. Mistrust and fear, prejudice against the unknown, caused mostly by a lack of information, bad experiences in implementation processes of other projects, were all problems to be faced. It was important to win over citizens, and interest groups like farmers, forest owners, hunters and others in the region. People had to be convinced of the advantages of a future designation of their region as a biosphere reserve. And more than that: as many multipliers and supporters in local communities, in various interest groups and businesses as possible had to be motivated to take an active role in the development of a model region for sustainability as a biosphere reserve according to the UNESCO guidelines.

Regarding the large area, the high number of residents, the large number of municipalities and the variety of different interests on the area, it is obvious that these goals in the field of communication could not be reached in full extent yet. It rather is a long, but absolutely necessary, communication and information process that has just started. However, the efforts made in this field so far can be considered a great success. Public awareness and acceptance has been raised up to a high level. There has never been even the slightest opposition against the project. Basic information about the biosphere reserve concept in general, about the question, why it is perfectly suitable for the Wienerwald region, about advantages and opportunities, etc. could be made accessible to a wide public. Probably the greatest success is that hundreds of multipliers such as may- ors and other representatives of local communities, representatives of interest groups in agriculture, tourism, forestry and other areas, nature protection organisations, teachers, journalists, scientists have already become active supporters of this project.

Numerous organisations in the Wienerwald region and the surrounding municipalities offer a wide range of programmes for environmental education. In the course of the extensive PR activities during the biosphere reserve planning phase the project under the title "living in the Biosphere Reserve Wienerwald - a pilot site for sustainable development" has been introduced, in cooperation with the Austrian Commission for UNESCO. In order to present the concept of the Biosphere Reserve in the schools in the Wienerwald region, teaching materials have been prepared. 